\title{
FATTY ACID COMPOSITION, CHOLESTEROL, AND FAT-SOLUBLE VITAMINS IN THE MUSCLE, LIVER, AND GONAD OF SHABBOUT (BARBUS GRYPUS, HECKEL 1843)
}

\author{
A.G. HARLIOĞLU* \\ Fisheries Faculty, Firat University, 23119, Elazığ. Turkey
}

(Received: 21 July 2012; accepted: 10 January 2013)

\begin{abstract}
The moisture, protein, fat, and ash contents of Barbus grypus muscle were $76.14,18.85,2.95$, and $0.83 \%$, respectively. The fatty acid composition of $B$. grypus showed that the amounts of saturated fatty acids (SFA) were significantly $(\mathrm{P}<0.05)$ higher $(34.88 \%)$ in the liver compared to the muscle $(30.18 \%)$. Of the SFA, the amount of palmitic acid was significantly $(\mathrm{P}<0.05)$ higher in the liver than that in the muscle and gonad. With regard to the monounsaturated fatty acids (MUFA), oleic acid content in the muscle $(23.46 \%)$ of B. grypus was significantly $(\mathrm{P}<0.05)$ higher than in the liver $(18.01 \%)$. The amounts of docosahexaenoic acid (C22:6n-3, DHA), eicosatetraenoic acid (C20:4 n-3), and eicosapentaenoic acid (C20:5 n-3, EPA) were predominantly found in the muscle, liver, and gonad. The amount of cholesterol in the liver and gonad was significantly higher than in the muscle. On the other hand, significantly higher $(\mathrm{P}<0.05)$ retinol, $\mathrm{D}_{3}, \delta$-tocopherol, and $\mathrm{K}_{1}$ vitamin values were found in the liver than in the muscle and gonad of this species.
\end{abstract}

Keywords: Barbus grypus, fatty acids, proximate composition, cholesterol, muscle, liver, gonad

Lipids are important components of animal and human diets both because of their role as energy providing molecules and due to the essential nature of some fatty acids. It has been reported that polyunsaturated fatty acids (PUFA), especially the n-3 PUFA, have been considered essential fatty acids as they were shown to have curative and preventive effects on cardiovascular disease, atherosclerosis, and thrombosis (CAHU et al., 2004). Long chain n-3 PUFA, including eicosapentaenoic acid and docosahexaenoic acid, are found in fish and seafoods (Osman et al., 2001).

Fatty acids are not only the major sources of metabolic energy in fish for growth from the egg to the adult fish, but for reproduction also. It has been indicated that the lipid composition of fish varies between and within species. Many factors appear to contribute to this variability, including fish size, maturity stage, food availability, catch area, location, season, and biological variations (ARAs et al., 2003).

Fishery is one of the most important sections of agriculture in Turkey. Turkey has a wide variety of freshwater and marine species comprising trout, carp, sea bass, sea bream, turbot, mussel, crayfish, etc. The total production of fish and shellfish was 653080 tons in 2010 . However, the contribution of freshwater and sea catch to total fishery production is relatively large. For example, capture fisheries production amounted to 485939 tons whilst aquaculture production was 167141 tons in the same year (ANON., 2010; HARLIOĞLU, 2011).

Aquaculture is going to play an increasingly important role in the Turkish economy, as fishery products are the only products of animal origin that can be exported to the EU. There has been a fast increase in the aquaculture production in Turkey. For example, total aquaculture

\footnotetext{
* To whom correspondence should be addressed.

Phone: 00904242370000 ext: 4549; fax: 0090424238 6287; e- mail: aharlioglu@firat.edu.tr
} 
production for 1986 and 2010 was 3075 tons and 167141 tons, respectively. The percentage of aquaculture in total fish production has been rising every year. The ratio of cultured fish production to total fish production was $1.5 \%$ in $1990 \mathrm{~s}, 13.57 \%$ in 2000 and more than $20 \%$ in 2005 . It was $24.59 \%$ in 2010 . Moreover, although Turkey has very rich inland waters and river systems, trout and carp are the only cultured freshwater fish species in the country (ANon., 1986-2010).

On the other hand, in recent years there has been an increase in the distribution and catch value of some economically important freshwater fish species in Turkey. These species mainly are Oncorhynchus mykiss, Cyprinus carpio, Mastacembelus simack, B. grypus, and Alburnus tarichii (HARLIOĞLu, 2011). Products that are harvested from inland waters in minor amounts are catfish, tench, mullet, wels, Transcaucasian barb (Capoeta capoeta capoeta), trout, pike, rudd (Scardinius erythrophthalmus) snails, frogs, and crayfish (HARLIOĞLU, 2011). These fish species, such as B. grypus, can be accepted as an aquaculture candidate in Turkey (GoKcE et al., 2011). For example in 2010, 73300 fry of B. grypus were produced to stock Atatürk Dam lake by the Fish Production Station of $152^{\text {th }}$ Branch Department Directorate of State Hydraulic Works, Şanlıurfa (ANON., 1986-2010).

The Barbus genus of Cyprinidae is widely distributed in Eastern Asia, Eastern Europe, and Africa. In addition, B. grypus is one of the most significant fish species listed in the freshwaters of Iraq and in the rivers along south and southwest Iran, Karoon river, and also in the Euphrates and Tigris Rivers in Turkey.

Fatty acid composition, cholesterol, and fat-soluble vitamin content are important factors in determining the nutritional quality of fish species. They are also important in pellet formulation (IzQUIERDO et al., 2001). Therefore, fatty acid composition, fat-soluble vitamin, and cholesterol content of wild B. grypus muscle, liver, and gonad were investigated in the present study. In addition, water, ash, protein, and fat values of B. grypus muscle were also analysed.

\section{Materials and methods}

Barbus grypus samples used in the present study were caught from Keban Dam Lake (Keban Dam Lake; $1097 \mathrm{~m}$ long and its crest is $207 \mathrm{~m}$ above the level of the river-bed $848 \mathrm{~m}$ above sea level and the surface area is $675 \mathrm{~km}^{2}$ ) in Elazığ, Turkey. Seven female B. grypus were obtained in January 2012 for the study. In this month the mean water temperature was $7.8^{\circ} \mathrm{C}$, dissolved oxygen concentration was $9.8 \mathrm{mg} \mathrm{l}^{-1}$ and $\mathrm{pH}$ was 7.7. Immediately, after catching, they were stored on ice in an insulated box and transferred in about two hours to the laboratory. The mean weight of B. grypus was $3831.2 \pm 474.9 \mathrm{~g}$. The samples provided were kept in deep freeze at $-30{ }^{\circ} \mathrm{C}$ until they were studied. The fish were beheaded, eviscerated, and homogenized.

\subsection{Proximate analysis}

Proximate analysis of the seven fish muscles was done following A.O.A.C. (1995) methods: dry matter was measured after drying at $105^{\circ} \mathrm{C}$ for $24 \mathrm{~h}$ to constant weight in an oven (a); proteins were determined by Kjeldahl analysis (nitrogen $\times 6.25$ ) (b); fat was determined by Soxhlet's apparatus with petroleum ether (c); ash content was determined by weighing after burning at $550^{\circ} \mathrm{C}(\mathrm{d})$. 


\subsection{Fatty acid, fat-soluble vitamin, and cholesterol analysis}

Extraction of lipids: the lipids of the muscle, liver, and gonad samples were extracted with hexane-isopropanol (3:2, v/v) according to the method of HARA and RADIN (1978). One gram sample was homogenized with $10 \mathrm{ml}$ hexane-isopropanol mixture. The homogenate was centrifuged at 5000 r.p.m. for $5 \mathrm{~min}$ at $4{ }^{\circ} \mathrm{C}$ and parts of tissue remnants were precipitated. The supernatant part was used in the analysis of fat-soluble vitamins (A, D, E, and $\mathrm{K}$ ), cholesterol, and fatty acids.

Preparation of fatty acid methyl esters: fatty acids in the lipid extracts were converted into methyl esters with $2 \%$ sulphuric acid (v/v) in methanol (CHRISTIE, 1992). The mixture was vortexed and then kept at $50{ }^{\circ} \mathrm{C}$ for $12 \mathrm{~h}$. Then, after being cooled to room temperature, $5 \mathrm{ml}$ of $5 \%$ sodium chloride was added and then it was vortexed. Fatty acid methyl esters were extracted with $2 \times 5 \mathrm{ml}$ hexane. Fatty acid methyl esters were treated with $5 \mathrm{ml} 2 \%$ $\mathrm{KHCO}_{3}$ solution and then the hexane phase was evaporated by nitrogen flow. After dissolving in $0.5 \mathrm{ml}$ fresh hexane (CHRISTIE, 1992), they were taken to auto sampler vials.

Gas chromatographic analysis of fatty acid methyl esters: methyl esters were analysed with the Shimadzu GC-17 Ver. 3 gas chromatograph (Kyoto, Japan). For this analysis, $25 \mathrm{~m}$ long Macherey-Nagel (Germany) capillary column with an internal diameter of $0.25 \mathrm{~mm}$ and a film thickness of $25 \mu \mathrm{m}$ was used. During the analysis, the column temperature program started from $110^{\circ} \mathrm{C}$ with a rate of $5{ }^{\circ} \mathrm{C} \mathrm{min}^{-1}$ until $200{ }^{\circ} \mathrm{C}$ and $4{ }^{\circ} \mathrm{C} \mathrm{min}-1$ from $200-220{ }^{\circ} \mathrm{C}$. It was kept at $220^{\circ} \mathrm{C}$ for $8 \mathrm{~min}$, the total duration was set as $35 \mathrm{~min}$. The injector temperature was kept at $240{ }^{\circ} \mathrm{C}$ and the detector temperature at $280^{\circ} \mathrm{C}$. The nitrogen carrier gas flow was $1 \mathrm{ml} \mathrm{min}{ }^{-1}$. The methyl esters of fatty acids were identified by comparison with authentic external standard mixtures analysed under the same conditions, and the Class GC 10 software version 2.01 was used to process the data.

HPLC analysis of ADEK vitamins and cholesterol: five $\mathrm{ml}$ supernatant was taken to $25 \mathrm{ml}$ tubes with caps and 5\% KOH solution was added and immediately vortexed for $20 \mathrm{~s}$. The tubes were placed in a water bath at $85{ }^{\circ} \mathrm{C}$ for $15 \mathrm{~min}$. The tubes were then cooled to room temperature and $5 \mathrm{ml}$ of distilled water was added and mixed. Lipophilic molecules that did not saponify were extracted with $2 \times 5 \mathrm{ml}$ hexane. The hexane phase was evaporated with nitrogen flow. It was dissolved in $1 \mathrm{ml}(50+50 \%$, v/v) acetonitrile/methanol mixture and then was taken to auto sampler vials and was analysed.

The analysis was made with the Shimadzu HPLC device. HPLC conditions were as follows: mobile phase 60:38:2 (v/v/v): acetonitrile:methanol:water. The mobile phase flow rate was determined to be $1 \mathrm{ml}$. A UV detector and a Supelcosil LC $18(15 \times 4.6 \mathrm{~cm} 5 \mu \mathrm{m}$; Sigma USA) column was used for the analysis. For vitamin E and cholesterol $202 \mathrm{~nm}$, for retinol $326 \mathrm{~nm}$, and for vitamin D and K $265 \mathrm{~nm}$ was used (KATSANIDIS \& ADDIS 1999; LóPEZCervantes et al., 2006).

The analyses outlined above were carried out in the biology department of the Life Science Faculty of Firat University.

\subsection{Statistical analysis}

The data on the fatty acid composition, fat-soluble vitamin, and cholesterol obtained from $B$. grypus muscle, liver, and gonad were analysed statistically using one-way analysis of variance (ANOVA), followed by Duncan's new multiple range test. Significant differences were based on the $\mathrm{P}<0.05$ level. The results were expressed as means \pm standard deviation. 


\section{Results and discussion}

\subsection{Proximate composition}

Moisture, protein, fat, and ash contents of B. grypus muscle averaged (mean $\pm \mathrm{SD}) 76.14 \pm 1.11$, $18.85 \pm 0.91,2.95 \pm 0.78$, and $0.83 \pm 0.57 \%$, respectively.

In comparison to the findings of the present study a higher ash content $(1.4 \%-1.7 \%)$ and similar moisture $(71.7 \%-76.1 \%)$, protein, and fat contents $(16 \%-21.6 \%$ and $2 \%-3.9 \%)$ were found by GокCE and co-workers (2011) for B. grypus caught from the Atatürk Dam Lake, Turkey. The findings of the present study were comparable with the reports for different fish species. For example, moisture, protein, ash, and fat contents were reported for wild Brycon orbignyanus $(73.15,18.94,1.19$, and $3.56 \%$, respectively) by MoREIRA and co-workers (2001); moisture, protein, ash, and fat contents for Mastacembelus simack (75.87, 17.06, 1.02 , and $10.92 \%$, respectively) by HARLIOĞLU and YiLmaz (2011).

\subsection{Fatty acid composition of muscle, liver, and gonad}

The fatty acid compositions in the muscle, liver, and gonad of B. grypus examined in the present study are listed in Table 1. It was determined that the total MUFA content of lipids was much higher $(36.22 \%)$ in the muscle of B. grypus than the SFA $(30.18 \%)$ and the lowest percentage was received for PUFA (26.08\%).

OSMAN and co-workers (2001) stated that freshwater fish have lower contents of PUFA because of the fact that freshwater fishes feed largely on vegetation and plant materials. In addition to this, freshwater fish have higher MUFA than SFA or PUFA contents. This was observed in B. grypus by GоKCE and co-workers (2011).

Among the SFA, the principal component was palmitic acid (C16:0) (18.31\% for muscle, $24.14 \%$ for liver, and $20.72 \%$ for gonad). These findings agree with other studies conducted on Sparus aurata muscle and liver by MNARI and co-workers (2007), on Esox lucius muscle, liver, and gonad by KANDEMIR (2010). In this study, the amount of palmitic acid was significantly $(\mathrm{P}<0.05)$ higher in the liver than in the muscle and gonad. In addition to this, the amount of SFA was higher in the liver than in the muscle and gonad. Similarly, MNARI and co-workers (2007) reported a slightly higher palmitic acid content in the liver $(21.43 \%)$ than in the muscle (19.41-19.34\%) for wild Sparus aurata.

In the present study it was determined that oleic acid (C18:1) was the primary MUFA in the muscle, liver, and gonad of female B. grypus. Furthermore, the oleic acid content in muscle $(23.46 \%)$ of $B$. grypus was significantly $(\mathrm{P}<0.05)$ higher than that in $B$. grypus liver (18.01\%) (Table 1). Similarly, oleic acid was found to be the major MUFA component in the muscle in Dicentrarchus labrax by FuENTES and co-workers (2010), in Sparus aurata by MNARI and co-workers (2007). Many fish tissues seem to contain excessive amounts of oleic acid within the total MUFA (ARAs et al. 2003). Therefore, KANDEMIR (2010) concluded that from the higher amount of oleic acid in the muscle, liver, and gonad of E. lucius, regarding the fact that the sampling coincides with the reproduction season, it is apparent that MUFA is used for energy purposes.

In this study with regard to PUFA, there is no significant difference $(\mathrm{P}>0.05)$ between the muscle $(33.58 \%)$, liver $(35.66 \%)$, and gonad (34.63\%) tissues. In comparison to the present study GоKCE and co-workers (2011) found lower PUFA levels (19.2 to $26.1 \%)$ in the muscle of B. grypus. In a different study, the PUFA content of some freshwater fish species was investigated by Donmez (2009). He found a similar PUFA, DHA+EPA, and lower n-3/n-6 
Table 1. Fatty acid composition (\% of total fatty acids) of muscle, liver, and gonad of B. grypus

\begin{tabular}{|c|c|c|c|}
\hline Fatty acids & Muscle & Liver & Gonad \\
\hline C14:0 & $1.33 \pm 0.72^{\mathrm{a}}$ & $1.68 \pm 0.55^{\mathrm{ab}}$ & $2.75 \pm 0.52^{\mathrm{a}}$ \\
\hline $\mathrm{C} 15: 0$ & $0.48 \pm 0.07^{\mathrm{a}}$ & $0.33 \pm 0.04^{\mathrm{b}}$ & $0.33 \pm 0.03^{\mathrm{b}}$ \\
\hline C16:0 & $18.31 \pm 1.33^{b}$ & $24.14 \pm 2.65^{\mathrm{a}}$ & $20.72 \pm 1.29^{b}$ \\
\hline C17:0 & $0.55 \pm 0.06^{\mathrm{a}}$ & $0.31 \pm 0.03^{\mathrm{b}}$ & $0.39 \pm 0.05^{\mathrm{b}}$ \\
\hline C18:0 & $5.17 \pm 1.24$ & $4.75 \pm 1.06$ & $4.81 \pm 1.02$ \\
\hline $\mathrm{C} 21: 0$ & $0.19 \pm 0.03$ & $0.13 \pm 0.04$ & nd* \\
\hline $\mathrm{C} 22: 0$ & $0.97 \pm 0.32$ & $0.75 \pm 0.07$ & $0.80 \pm 0.08$ \\
\hline $\mathrm{C} 24: 0$ & $3.18 \pm 0.24^{\mathrm{a}}$ & $2.79 \pm 0.19^{\mathrm{a}}$ & $2.1 \pm 0.21^{\mathrm{b}}$ \\
\hline$\Sigma$ SFA & $30.18 \pm 0.85^{b}$ & $34.88 \pm 4.65^{\mathrm{a}}$ & $31.90 \pm 1.73^{\mathrm{ab}}$ \\
\hline C14:1 & $0.27 \pm 0.03^{\mathrm{a}}$ & $0.13 \pm 0.04^{b}$ & $0.22 \pm 0.04^{\mathrm{ab}}$ \\
\hline C15:1 & $1.85 \pm 0.51$ & $1.55 \pm 0.35$ & $1.54 \pm 0.32$ \\
\hline C16:1 n-7 & $8.57 \pm 1.32^{\mathrm{ab}}$ & $7.51 \pm 0.86^{\mathrm{b}}$ & $9.94 \pm 0.57^{\mathrm{a}}$ \\
\hline $\mathrm{C} 17: 1$ & $0.31 \pm 0.06$ & $0.36 \pm 0.09$ & $0.3 \pm 0.07$ \\
\hline C18:1 n-9 & $23.46 \pm 2.17^{\mathrm{a}}$ & $18.01 \pm 1.34^{\mathrm{b}}$ & $19.55 \pm 2.43^{\mathrm{ab}}$ \\
\hline C20:1 n-9 & $1.45 \pm 0.31$ & $1.36 \pm 0.22$ & $1.66 \pm 0.19$ \\
\hline $\mathrm{C} 22: 1$ & $0.31 \pm 0.09$ & $0.35 \pm 0.03$ & $0.22 \pm 0.01$ \\
\hline$\Sigma$ MUFA & $36.22 \pm 3.43^{\mathrm{a}}$ & $29.27 \pm 2.95^{b}$ & $33.43 \pm 2.50^{\mathrm{ab}}$ \\
\hline C18:2 n-6 & $5.52 \pm 1.03$ & $4.08 \pm 1.13$ & $3.69 \pm 1.09$ \\
\hline$C 20: 2$ n-6 & $0.38 \pm 0.12$ & $0.42 \pm 0.11$ & $0.26 \pm 0.06$ \\
\hline$C 22: 2 n-6$ & $0.52 \pm 0.11$ & $0.73 \pm 0.24$ & $0.67 \pm 0.18$ \\
\hline C20:4 n-6 & $1.08 \pm 0.37$ & $0.95 \pm 0.35$ & $1.20 \pm 0.59$ \\
\hline$\Sigma \mathrm{n}-6$ & $7.5 \pm 1.12$ & $6.18 \pm 1.61$ & $5.82 \pm 2.09$ \\
\hline C18:3 n-3 & $2.49 \pm 0.7^{\mathrm{a}}$ & $1.14 \pm 0.33^{\mathrm{b}}$ & $1.86 \pm 0.22^{\mathrm{ab}}$ \\
\hline C20:4 n-3 & $5.93 \pm 1.17^{\mathrm{b}}$ & $7.32 \pm 1.62^{\mathrm{ab}}$ & $8.93 \pm 1.85^{\mathrm{a}}$ \\
\hline$C 20: 5 n-3$ & $4.99 \pm 0.33^{b}$ & $5.94 \pm 0.32^{\mathrm{a}}$ & $4.31 \pm 0.36^{\mathrm{c}}$ \\
\hline$C 22: 5 n-3$ & $1.17 \pm 0.27$ & $1.33 \pm 0.33$ & $0.85 \pm 0.28$ \\
\hline$C 22: 6 n-3$ & $11.5 \pm 2.95$ & $13.75 \pm 2.47$ & $12.86 \pm 1.33$ \\
\hline$\Sigma \mathrm{n}-3$ & $26.08 \pm 2.60$ & $29.48 \pm 1.85$ & $28.81 \pm 3.10$ \\
\hline$\Sigma$ PUFA & $33.58 \pm 2.32$ & $35.66 \pm 1.37$ & $34.63 \pm 1.63$ \\
\hline$n-3 / n-6$ & $3.47 \pm 0.76$ & $4.78 \pm 1.59$ & $4.95 \pm 1.78$ \\
\hline DHA/EPA & $2.30 \pm 0.72$ & $2.31 \pm 0.29$ & $2.98 \pm 0.44$ \\
\hline DHA+EPA & $16.49 \pm 2.81$ & $19.69 \pm 2.80$ & $17.17 \pm 1.32$ \\
\hline PUFA/SFA & $1.11 \pm 0.08$ & $1.02 \pm 0.13$ & $1.08 \pm 0.06$ \\
\hline
\end{tabular}

Superscripts in a row with different letters represent significant difference $(\mathrm{P}<0.05)$. Each value is the mean $\pm \mathrm{SD}$ of seven replicates.* nd: not determined

content in the muscle of Cprinus carpio, Carassius carassius, Leusiscus cephalus, and Tinca tinca. OsMAN and co-workers (2001) reported higher PUFA levels (56.8-89.5\%) in muscle of marine fish in Malaysian waters. However, Moreira and co-workers (2001) determined lower PUFA contents in the muscle of wild B. microlepis $(12.02 \%)$ and B. orbignyanus (7.19\%). In this study, B. grypus livers were rich in PUFA and DHA+EPA, and had favourable n-3/n-6 ratios (Table 1). KANDEMIR (2010) reported high PUFA and DHA+EPA levels, and good n-3/n-6 ratio in muscle, liver, and gonad of E. lucius. It has been suggested that the n-3/n-6 ratio can be used as an index to compare the relative nutritional value of fish oils belonging to different species, and it has been estimated a diet ratio from 4:1 to 1:1 during human evolution (PIgGOTT \& TuCKER, 1990). The results of this study revealed that the ratio 
of n-3 to n-6 fatty acids was $3.47,4.78$, and 4.95 in muscle, liver, and gonad, respectively. KANDEMIR (2010) found that n-3/n-6 ratio in pike was the highest in the liver with $6.13 \%$, which was followed by the muscle with $4.98 \%$, and gonad with $2.33 \%$. On the other hand, the findings of the present study were comparable with the reports for different fish species. For example, n-3/n-6 ratio was reported for B. grypus muscle as 2.4-4.8 by GoKCE and coworkers (2011); for Salmo trutta labrax as 6.27 by ARAS and co-workers (2003).

For the three tissue samples our study revealed that B. grypus contained more total n-3 PUFA than total n-6 PUFA. Linoleic acid (C18:2n-6) was the primary and arachidonic acid (C20:4 n-6) the second important n-6 PUFA in all tissues. Docosahexaenoic acid was the principal n-3 PUFA in all tissues. Eicosatetraenoic acid and eicosapentaenoic acid were found in higher amounts in all tissues than other n-3 PUFA. Eicosatetraenoic acid can modulate eicosanoid production in mammalian cell systems. In female sparid, it has been assumed that PUFA, such as EPA and DHA, are involved in the physiological reproductive processes. Arachidonic acid and EPA are the major eicosanoid precursors in fish cells, including prostaglandins, thromboxans, and leukotrienes among others (IzQUIERDo et al., 2001).

In the present study, PUFA/SFA was found to be $1.11,1.02$, and 1.08 in B. grypus muscle, liver, and gonad, respectively. Concerning the PUFA/SFA ratio the values found were $1.65,0.92$, and 1.16 in wild E. lucius muscle, liver, and gonad, respectively, by KANDEMIR (2010). The PUFA/SFA ratio in the muscle of E. lucius was much higher than that in $B$. grypus in the present study, due to the high proportion of PUFA in the muscle of E. lucius. WooD and co-workers (2003) reported that a ratio of 0.45 or more is recommended as a balanced fatty acid intake in a healthy diet. Therefore, the results obtained in the present study revealed a PUFA/SFA ratio of 1.11 for muscle, which is within the recommended range.

\subsection{Fat-soluble vitamins and cholesterol content of muscle, liver, and gonad}

In the present study retinol, retinol acetate, $\mathrm{D}_{2}, \mathrm{D}_{3}, \delta$-tocopherol, $\alpha$-tocopherol, and $\mathrm{K}_{1}$ and $\mathrm{K}_{2}$ vitamin contents in the muscle of $B$. grypus were determined as $0.46 \pm 0.27 \mu \mathrm{g} \mathrm{g}^{-1}, 0.14 \pm 0.08$ $\mu \mathrm{g} \mathrm{g}^{-1}, 0.65 \pm 0.32 \mu \mathrm{g} \mathrm{g}^{-1}, 0.98 \pm 0.41 \mu \mathrm{g} \mathrm{g}^{-1}, 0.52 \pm 0.30 \mu \mathrm{g} \mathrm{g}^{-1}, 26 \pm 6.41 \mu \mathrm{g} \mathrm{g}^{-1}, 0.41 \pm 0.24 \mu \mathrm{g}$ $\mathrm{g}^{-1}$, and $5.01 \pm 1.67 \mu \mathrm{g} \mathrm{g}^{-1}$, respectively (Table 2). A study on the vitamin content of fish and fish products consumed in Portugal was undertaken by DiAs and co-workers (2003), who found that vitamins $\mathrm{A}, \mathrm{D}$, and $\mathrm{E}$ in sea bass meat were 36 and $5 \mu \mathrm{g} / 100 \mathrm{~g}$ and $0.17 \mathrm{mg} / 100 \mathrm{~g}$, respectively. In salmon, these values were found to be 33 and $11 \mu \mathrm{g} / 100 \mathrm{~g}$ and $4.0 \mathrm{mg} / 100 \mathrm{~g}$, and in rainbow trout as 8.8 and $19 \mu \mathrm{g} / 100 \mathrm{~g}$ and $0.13 \mathrm{mg} / 100 \mathrm{~g}$, respectively (DIAs et al., 2003).

In the present study, the highest amount of retinol, $\mathrm{D}_{3}, \delta$-tocopherol, and $\mathrm{K}_{1}$ vitamin were found in the liver with $10.75,2.55,1.27$, and $2.52 \mu \mathrm{g} \mathrm{g}^{-1}$, respectively, and the difference between the muscle and gonad was significant $(\mathrm{P}<0.05)$ (Table 2$)$. However, there was no significant difference $(\mathrm{P}>0.05)$ between the muscle, liver, and gonad with regard to the $\mathrm{D}_{2}$ and $\alpha$-tocopherol values. KANDEMIR (2010) reported higher amounts of $\alpha$-tocopherol, a precursor of vitamin E, and that there is a strong correlation between the PUFA and $\alpha$-tocopherol requirement, and $\alpha$-tocopherol directly necessitates PUFA consumption. In this study with regard to PUFA, there is no significant difference $(\mathrm{P}>0.05)$ between the muscle, liver, and gonad tissues. In addition to this, IZQUIERDO and co-workers (2001) reported that vitamin E deficiency affects reproductive performance, causing immature gonads and lower hatching rate and survival of offspring. In the present study, the highest amount of $\mathrm{K}_{2}$ vitamin was 
found in the gonad. Similarly, KandemiR (2010) also found that higher amount of $\mathrm{K}_{2}$ vitamin was found in the $\operatorname{gonad}\left(31.7 \mu \mathrm{g} \mathrm{g}^{-1}\right)$ than in other tissues of E. lucius.

Table 2. The fat-soluble vitamins and cholesterol content of muscle, liver, and gonad of B. grypus

\begin{tabular}{lccc}
\hline $\begin{array}{l}\text { Vitamin }\left(\mu \mathrm{g} \mathrm{g}^{-1}\right) \text { and } \\
\text { cholesterol } \\
(\mathrm{mg} / 100 \mathrm{~g})\end{array}$ & Muscle & Liver & Gonad \\
\hline Retinol & & & \\
Retinol acetate & $0.46 \pm 0.27^{\mathrm{b}}$ & $10.75 \pm 3.86^{\mathrm{a}}$ & $0.85 \pm 0.44^{\mathrm{b}}$ \\
$\mathrm{D}_{2}$ & $0.14 \pm 0.08$ & $0.19 \pm 0.05$ & nd $^{*}$ \\
$\mathrm{D}_{3}$ & $0.65 \pm 0.32$ & $0.82 \pm 0.45$ & $0.33 \pm 0.21$ \\
$\delta$-tocopherol & $0.98 \pm 0.41^{\mathrm{b}}$ & $2.55 \pm 1.04^{\mathrm{a}}$ & $0.46 \pm 0.22^{\mathrm{b}}$ \\
$\alpha$-tocopherol & $0.52 \pm 0.30^{\mathrm{b}}$ & $1.27 \pm 0.59^{\mathrm{a}}$ & $0.57 \pm 0.29^{\mathrm{b}}$ \\
$\mathrm{K}_{1}$ & $26.0 \pm 6.41$ & $28.50 \pm 6.65$ & $21.5 \pm 5.01$ \\
$\mathrm{~K}_{2}$ & $0.41 \pm 0.24^{\mathrm{b}}$ & $2.52 \pm 0.87^{\mathrm{a}}$ & $0.44 \pm 0.33^{\mathrm{b}}$ \\
$\mathrm{Cholesterol}^{\mathrm{b}}$ & $5.01 \pm 1.67^{\mathrm{b}}$ & $5.40 \pm 1.17^{\mathrm{b}}$ & $8.87 \pm 2.84^{\mathrm{a}}$ \\
\hline
\end{tabular}

Superscripts in a row with different letters represent significant difference $(\mathrm{P}<0.05)$. Each value is the mean $\pm \mathrm{SD}$ of seven replicates. ${ }^{*}$ nd: not determined

The cholesterol content of B. grypus in the muscle, liver, and gonad were found to be $46.44,185.6$, and $203.2 \mathrm{mg} / 100 \mathrm{~g}$, respectively, in the present study (Table 2). In comparison, ŽIVKović and co-workers (2002) found lower cholesterol content (below $20 \mathrm{mg} / 100 \mathrm{~g}$ ) in the muscle of five Cyprinidae species (Blicca bjoerkna L., Abramis brama L., Vimba vimba carinata Pallas, Abramis balerus L., and Carassius carassius gibelio Bloch). On the other hand, ŽIVKović and co-workers (2002) found that cholesterol content varied in different seasons. OSMAN and co-workers (2001) stated that cholesterol content in fish is influenced by, among several factors, the PUFA content, an increase in PUFA content will be followed by a decrease in the cholesterol level.

\section{Conclusions}

In conclusion, high levels of palmitic acid, oleic acid, palmitoleic acid, DHA, eicosatetraenoic acid, and EPA accumulate in the muscle, liver, and gonad. The percentage of eicosatetraenoic acid was significantly higher in the gonad than in the muscle. In addition, B. grypus muscle is rich in protein, unsaturated fatty acids, but its cholesterol level is low. Furthermore, it has reasonable PUFA/SFA and n-3/n-6 ratios and is rich in fat-soluble vitamins as recommended by nutritionists.

\section{References}

A.O.A.C. (1995): Official Methods of Analysis. Association of Official Analytical Chemists (A.O.A.C.) 16 ${ }^{\text {th }}$ ed., Arlington, VA. a: Moisture in animal feed. No. 925.04; b: Nitrogen determination by Kjeldahl (Block digestion). No. 981.10; c: Fat (crude) in meat and poultry products. Rapid microwave-solvent extraction method No. 985.15; d: Ash of seafood. No. 938.08.

ANON. (1986-2010): Yearly fishery statistics. Prime Ministry of Turkey, Turkish Statistical Institute (TURKSTAT), Ankara, Turkey. 
Aras, N.M., HaliloĞLu, İ. \& AyıK, Ö. (2003): Comparison of fatty acid profiles of different tissues of mature trout (Salmo trutta labrax, Palas, 1811) caught from Kazandere Creek in the Çoruh region, Erzurum, Turkey. Türk. J. Vet. Anim. Sci., 27, 311-316.

Cahu, C., Salen, P. \& De Lorgeril, M. (2004): Farmed and wild fish in the prevention of cardiovascular diseases: assessing possible differences in lipid nutritional values. Nutr. Metab. Cardiovasc. Dis., 14, 34-41.

Christie, W.W. (1992): Gas chromatography and lipids. The Oil Press, Glasgow, 302 pages.

Dias, M.G., Sanchez, M.V. Bartolo, H. \& Oliveira, L. (2003): Vitamin content of fish and fish products consumed in Portugal. Electron. J. Environ. Agric. Fd Chem., (EJEAFChe), 2, 510-513.

Donmez, M. (2009): Determination of fatty acid compositions and cholesterol levels of some freshwater fish living in Porsuk Dam Lake, Turkey. Chem. Nat. Compounds, 45, 14-17.

Fuentes, A., Fernandez-Segovia, I., Serra, J.A. \& Barat, J.M. (2010): Comparison of wild and cultured sea bass (Dicentrarchus labrax) quality. Fd Chem., 119, 1514-1518.

Gokce, M.A., Tasbozan, O., Tabakoglu, S.S., Celik, M., Ozcan, F. \& Basusta, A. (2011): Proximate composition and fatty acid profile of shabbout (Barbus grypus Heckel). J Fd Agric. Environ., 9, 148-151.

HARA, A. \& RAdin, N.S. (1978): Lipid extraction of tissues with a low-toxicity solvent. Anal. Biochem., 90, $420-426$.

Harlioğlu, A.G. (2011): Present status of fisheries in Turkey. Rev. Fish. Biol. Fish., 21, 667-680.

Harlioğlu, A.G. \& Yilmaz, Ö. (2011): Fatty acid composition, cholesterol and fat-soluble vitamins of wild-caught freshwater spiny eel, Mastacembelus simack (Walbaum, 1792). J. Appl. Ichthyol., 27, 1123-1127.

Izquierdo, M.S., Fernandez-Palacios, H. \& Tacon, A.G.J. (2001): Effect of broodstock nutrition on reproductive performance of fish. Aquaculture, 19, 25-42.

KANDEMIR, S. (2010): The fatty acid composition and cholesterol and vitamin contents of different muscles of Esox lucius (Linnaeus, 1758) living in lake Ladik. J. Anim. Vet. Adv., 9, 1179-1190.

Katsanidis, E. \& AdDis, P.B. (1999): Novel HPLC analysis of tocopherols and cholesterol in issue. Free Radic. Biol. Med., 27, 1137-1140.

López-Cervantes, J., SÁnchez-Machado, D.I. \& Ríos-VÁzquez N.J. (2006): High-performance liquid chromatography method for the simultaneous quantification of retinol, alpha-tocopherol, and cholesterol in shrimp waste hydrolysate. J. Chromatogr. A, 1105, 135-139.

Moreira, A.B., Visentainer, J.V., De Souza, N.E. \& Matsushita, M. (2001): Fatty acids profile and cholesterol contents of three Brazilian Brycon freshwater fishes. J. Fd Comp. Anal., 14, 565-574.

Mnari, A., Bouhlel, I., Chraief, I., Hammami, M., Romdhane, M.S., El Cafsi, M. \& Chaouch, A. (2007): Fatty acids in muscle and liver of Tunisian wild and farmed gilthead sea bream, Sparus aurata. Fd Chem., 100, 13931397.

Osman, H., Suriah, A.R. \& Law, E.C. (2001): Fatty acid composition and cholesterol content of selected marine fish in Malaysian waters. Fd Chem., 73, 55-60.

Piggott, G.M. \& Tucker, B.W. (1990): Effects of technology on nutrition. Marcel Dekker, New York, NY, pp. 3265.

Žrvković, D., Perić, V., Barać, M. \& Perunović, M. (2002): Cholesterol content in meat of some Cyprinidae. J. Agric Sci., 47, 179-187.

Wood, J.D., Richardson, G.R., Nute, G.R., Fisher, A.V., Campo, M.M., Kasapidou E., Sheard, P.R. \& Enser, M. (2003): Effects of fatty acids on meat quality: a review. Meat Sci., 66, 21-32. 